\title{
An Online Survey: Assessing Anxiety Level among General Population during the Coronavirus Disease-19 Pandemic in Indonesia
}

\author{
Kholisotul Hikmah ${ }^{1 *}$, Lucky Prisandy ${ }^{2}$, Gea Melinda ${ }^{3}$, M. Ibraar Ayatullah ${ }^{4}$ \\ ${ }^{1}$ Department of Epidemiology, Faculty of Public Health, Universitas Indonesia, Depok, West Java, Indonesia; ${ }^{2}$ Department of \\ Nursing, Poltekkes Kemenkes Pontianak, Pontianak, West Kalimantan, Indonesia; ${ }^{3}$ Department of Public Health, Graduate \\ School of Health Sciences, Kobe University, Kobe, Japan; ${ }^{4}$ Department of Dental Health, Poltekkes Kemenkes Kupang, \\ Kupang, East Nusa Tenggara, Indonesia
}

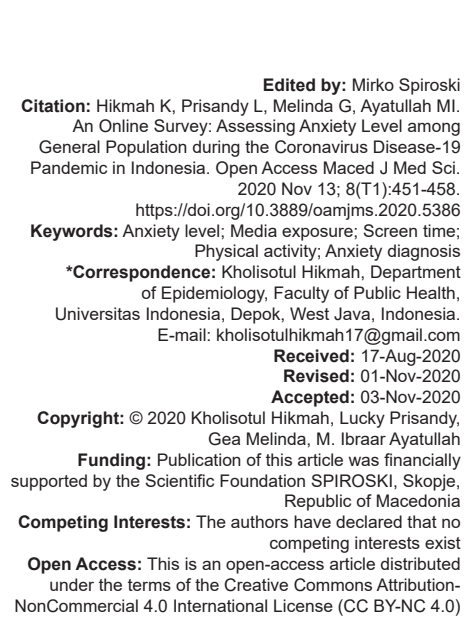

\section{Introduction}

A novel coronavirus, designated as 2019-nCov, was identified with the first outbreak since December 2019 in Wuhan, Hubei Province, China [1]. The disease caused by the novel coronavirus was named coronavirus disease 2019 (COVID-19). This virus is affecting 213 countries and territories around the world, including Indonesia [2].

The first confirmed case of COVID-19 in Indonesia was announced on March 10, 2020. Since then, the cases have been increasing drastically. As of June 10, 2020, the government has reported 34,316 people with confirmed COVID-19. There have been 1959 deaths and 12,129 patients have recovered from the disease [3]. In response to this situation, the Indonesia government has made new public policy, such as mandatory isolation for individuals coming back from red zone-regions, working from home, school suspensions, shutdown of non-essential administrations, and large scale social restriction [4]. These policies are typically implemented during a pandemic for an uncertain period. Furthermore, since Indonesia is the fourth most populated country in the world, the COVID-19 pandemic is anticipated to endure enormously over a more extended timeframe compared to other less populated nations. Indonesians, like the rest of the world, are increasingly concerned about these changes. A case report of anxiety disorderrelated COVID-19 outbreak in Indonesia showed that a 23-year-old female student initially experienced a feeling of anxiety symptoms such as heaviness in the chest, difficult breathing, and palpitation [5]. However, few investigations have detailed the effect of COVID-19 pandemic on anxiety levels among Indonesians despite that the pandemic has seriously influenced this country.

Anxiety, which may be defined as the pathological counterpart of normal fear, is identified by disturbance of mood, thinking, behavior, and 
psychological activity. It causes feelings of fear to predominate, out of proportion to any threat [6]. Everyone may experience anxiety at a different level and intensity; however, these different levels of anxiety and worry will be important when causing clinically significant distress or impairment in social, occupational, or other major areas of functioning. People with generalized anxiety disorder typically experience anxiety and worry alongside three or more of the following symptoms for at least 6 months: Muscle tension, early fatigue, restlessness, difficulty concentrating, irritability, and sleep disturbance [7].

The uncertainties and changes in daily life may lead to uneasiness among the population. The pandemic has provoked people to have stress and anxiety. During 2015-2016, large outbreaks of Zika virus occurred that increased anxiety [8]. The same trend holds for this pandemic; a recent study proved the association of the COVID-19 pandemic with an increase in stress among citizens in China [9]. This worry can be related to the continuing coronavirus spike. The general population has also been advised by authorities to decrease voyaging and stay at home as a fundamental method for constraining individuals' exposure to the virus. Unfortunately, the restriction on travel and directives on preventing participation in outdoor activities, including regular physical activity, would inevitably disrupt the routine daily activities. Since there is much uncertainty as to the current situation, people tend to feel plagued. Worrying refers to the psychological process of having rehashed negative and catastrophic considerations and is identified with discouragement and a few anxietyrelated issues [10], [11].

Although staying at home provides safety during a pandemic, it may have unintended negative consequences. In general, there is an extended time sitting or resting for screening activities (playing games, watching television, and utilizing cell phones), which lessens normal physical movement [12], [13].

Another potential anxiety factor is media exposure. During the COVID-19 outbreak, more exposure to threatening news, for example, reading about the number of new deaths, data on social media, and so forth, would increase fear of the virus. A previous study showed that media news about COVID-19 could trigger high levels of worry among the community, and it might consequently be a risk factor for depression and anxiety [14]. Threat information has shown that the mass media may become a conduit that spreads negative consequences of community trauma beyond directly affected communities [15], [16].

Furthermore, the COVID-19 pandemic may be associated with exacerbating pre-existing mental illnesses, especially anxiety disorders [17]. Therefore, we examined the diagnosis of an anxiety disorder as one factor that may induce anxiety in a large general population survey.
Previous studies have examined anxiety using a questionnaire that has been adjusted to pandemic situations. On the other hand, the current study applied a validated questionnaire to measure anxiety levels using the Hamilton Anxiety Rating Scale (HAM-A). Several studies also correlated anxiety during the pandemic era to media exposure only without considering screen time increment. To the best of our knowledge, there is no previous study that investigated anxiety during the pandemic period in Indonesia. Thus, we considered current research is essential to analyze anxiety within multicultural society in Indonesia during this COVID-19 pandemic.

This study aims to investigate the association between predisposition variables (age, gender, education, occupation, income, and current living place), physical activity, screen time, media exposure, and history of anxiety with current anxiety levels among Indonesian people during pandemic.

\section{Methods}

\section{Sample size determination}

Participants for this research were selected through an online survey using Google Form shared through social media (e.g., Whatsapp, Facebook, and Instagram). A total of 354 respondents (all over 18 years old) consented to participate; however, 87 respondents did not fill out the survey correctly. As a result, the last sample size of 267 people (representing 10 different provinces in Indonesia) was used for the rest of the study based on an a priori power calculation [15].

Data collection started on June 10, 2020, and was culminated on June 15,2020 , since it met the initial target sample size.

\section{Measures}

\section{Anxiety level}

During the pandemic, the anxiety level was measured using the Indonesian version of the HAM-A which fulfills the criteria of reliable (Cronbach's alpha $=0.756$ ) and valid (Pearson correlation ranged from 0.529 to 0.727 ) [18]. This questionnaire consists of 14 indicators, that is, anxious mood, tension, fears, insomnia, intellectual, depressed mood, somatic (muscular), somatic (sensory), cardiovascular symptoms, respiratory symptoms, gastrointestinal symptoms, genitourinary symptoms, autonomic symptoms, and behavior at interview. Respondents were asked to rate their frequency of 
experiencing the former symptoms on a 4-point scale: 0 (not present), 1 (mild), 2 (moderate), and 3 (severe). The total anxiety score could range between 0 and 56 ; an anxiety score <17 indicates mild severity, 18-24 stands for mild to moderate severity, and 25-30 denotes a moderate to severe level.

\section{Media exposure}

To measure voluntary exposure to news about COVID, respondents were asked to answer the following questions: "Have you looked for any extra information on the COVID-19 outbreak in any kind of media?" (with a yes or no answer). If they answered yes, they were also asked about the frequency of this action per week.

\section{Physical activity}

Physical activities during the COVID-19 pandemic were measured by the International Physical Activity Questionnaire-Short Form. Overall, the IPAQ questionnaires demonstrated strong validity $(r=0.72-0.82)$ and reliable (Cronbach's alpha $=0.63$ ) [19]. This form includes open-ended questions about the individuals' last 7-day recall of any physical activity. The data processing and analysis of this measure resulted in three categories, including low, moderate, and high.

\section{Screen time}

Subjects were asked to provide information on two items about screen time; first, "Do they always work online or through screen devices before the pandemic? Second, How much time do they spend in front of a device for work per day?"

\section{Anxiety diagnosis}

Respondents were asked whether they have been diagnosed with depression by a doctor or psychotherapist (over the past 12 months).

\section{Analytic approach}

Data analysis was performed by SPSS v20 software, and the statistical significance level was set at $p<0.05$. Demographic characteristics were split based on gender and summarized using descriptive statistics. Chi-square was employed to compare demographics associated with anxiety levels. Moreover, ordinal logistic regression analysis was performed to identify factors associated with anxiety by determining the odds ratio (OR) value.

\section{Results}

\section{Demographic characteristics}

Table 1 lists the demographic information of the respondents (267 participants in total; about 33.3\% male and $66.7 \%$ female).

Table 1: Demographic information of the respondents

\begin{tabular}{|c|c|c|c|c|}
\hline Variables & $\begin{array}{l}\text { Total } \\
(n=267)\end{array}$ & $\begin{array}{l}\text { Females } \\
(\mathrm{n}=178)\end{array}$ & $\begin{array}{l}\text { Males } \\
(\mathrm{n}=89)\end{array}$ & $\mathrm{p}$-value \\
\hline \multicolumn{5}{|l|}{ Age } \\
\hline $18-29$ & $168(62.9)$ & $113(63.5)$ & $55(61.8)$ & \multirow[t]{3}{*}{$>0.05$} \\
\hline $30-49$ & $86(32.2)$ & $59(33.1)$ & $27(30.3)$ & \\
\hline $50-69$ & $13(4.9)$ & $6(3.4)$ & $7(7.9)$ & \\
\hline \multicolumn{5}{|l|}{ Education level } \\
\hline Primary school education & $1(0.4)$ & $0(0)$ & $1(0.6)$ & \multirow[t]{3}{*}{$<0.01$} \\
\hline Secondary education & $21(7.9)$ & $15(16.9)$ & $6(3.4)$ & \\
\hline Higher education & $245(91.8)$ & 74 (83.1) & $171(96.1)$ & \\
\hline \multicolumn{5}{|l|}{ Occupation } \\
\hline Unemployed & $7(2.6)$ & $3(1.7)$ & $4(4.5)$ & \multirow[t]{3}{*}{$>0.05$} \\
\hline Full-time employed & $235(88.0)$ & $161(90.4)$ & $74(83.1)$ & \\
\hline Part-time employed & $25(9.4)$ & $14(7.9)$ & $11(12.4)$ & \\
\hline \multicolumn{5}{|l|}{ Current residence } \\
\hline Urban & $215(80.5)$ & $145(81.5)$ & $70(78.7)$ & \multirow[t]{2}{*}{$>0.05$} \\
\hline Rural & $52(19.5)$ & $33(18.5)$ & $19(21.3)$ & \\
\hline \multicolumn{5}{|l|}{ Income } \\
\hline Decrease & $78(29.2)$ & $50(28.1)$ & $28(31.5)$ & \multirow[t]{3}{*}{$<0.01$} \\
\hline Stable & $182(68.2)$ & $127(71.3)$ & $55(61.8)$ & \\
\hline Increase & $7(2.6)$ & $1(0.6)$ & $6(6.7)$ & \\
\hline
\end{tabular}

Based on the age demographics of the respondents, $62.9 \%$ of the respondents were 18-29 years old. Furthermore, $91.8 \%$ of the participants were university students, and $88 \%$ of the respondents were full-time employees. The current residence was categorized into urban and rural areas, showing that most respondents lived in urban areas (80.5\%). From a financial viewpoint, compared to the time before the COVID-19 pandemic, $68.2 \%$ of the respondents had a stable income, $29.2 \%$ and $2.6 \%$ experienced decreases and increases in their incomes, respectively.

\section{Anxiety level}

Table 2 presents the anxiety level among the population. Overall, most of the respondents had mild anxiety $(67.4 \%)$, and $11.6 \%$ only experienced severe anxiety.

Table 2: Anxiety level in frequency and percentage

\begin{tabular}{lll}
\hline Anxiety level & Frequency & $\%$ \\
\hline Severe & 31 & 11.6 \\
Moderate & 36 & 13.5 \\
Mild & 180 & 67.4 \\
Normal & 20 & 7.5 \\
\hline
\end{tabular}

Table 3 lists the frequency distribution of anxiety levels based on the characteristics of the respondents.

The data attribute severe anxiety mostly to women, 18-29 years old, and higher education. Respondents with full-time work tended to experience severe anxiety more than others. Those living in an urban area with stable incomes were at risk of anxiety.

Anxiety level significantly correlated across age, education, and income ( $p<0.05)$. 
Table 3: Distribution of the respondents' anxiety levels

\begin{tabular}{|c|c|c|c|c|}
\hline \multirow[t]{2}{*}{ Characteristics } & \multicolumn{4}{|l|}{ Anxiety level } \\
\hline & Severe n (\%) & Moderate n (\%) & Mild n (\%) & Normal n (\%) \\
\hline \multicolumn{5}{|l|}{ Gender } \\
\hline Male & $8(25.8)$ & $10(27.8)$ & $62(34.4)$ & $9(45)$ \\
\hline Female & $23(74.2)$ & $26(72.2)$ & $118(65.6)$ & $11(55)$ \\
\hline Chi-square & & $>0.05$ & & \\
\hline \multicolumn{5}{|l|}{ Age } \\
\hline $18-29$ & $23(74.2)$ & $30(83.3)$ & $107(59.4)$ & $8(40)$ \\
\hline $30-49$ & $7(22.6)$ & $5(13.9)$ & $62(34.4)$ & $12(60)$ \\
\hline $50-69$ & $1(3.2)$ & $1(2.8)$ & $11(6.1)$ & $0(0)$ \\
\hline Chi-square & & 0.010 & & \\
\hline \multicolumn{5}{|l|}{ Education level } \\
\hline Primary education & $0(0)$ & $0(0)$ & $0(0)$ & $1(5)$ \\
\hline Secondary education & $2(6.5)$ & $4(11.1)$ & $13(7.2)$ & $2(10)$ \\
\hline High education & 29 (93.5) & $32(88.9)$ & $167(92.8)$ & $17(85)$ \\
\hline Chi-square & & 0.039 & & \\
\hline \multicolumn{5}{|l|}{ Occupation } \\
\hline Unemployed & $2(6.5)$ & $1(2.8)$ & $4(2.2)$ & $0(0)$ \\
\hline Full-time employed & $27(87.1)$ & $30(83.3)$ & $160(88.9)$ & $18(90)$ \\
\hline Part-time employed & $2(6.5)$ & $5(13.9)$ & $16(8.9)$ & $2(10)$ \\
\hline Chi-square & & $>0.05$ & & \\
\hline \multicolumn{5}{|l|}{ Current residence } \\
\hline Urban & 29 (93.5) & $29(80.6)$ & $144(80)$ & $13(65)$ \\
\hline Rural & $2(6.5)$ & 7 (19.4) & $36(20)$ & $7(35)$ \\
\hline Chi-square & & $>0.05$ & & \\
\hline \multicolumn{5}{|l|}{ Income } \\
\hline Decrease & $14(45.2)$ & $17(47.2)$ & $42(23.3)$ & $5(25)$ \\
\hline Stable & $17(54.8)$ & $18(50)$ & $133(73.9)$ & $14(70)$ \\
\hline Increase & $0(0)$ & $1(2.8)$ & $5(2.8)$ & $1(5)$ \\
\hline Chi-square & & 0.034 & & \\
\hline
\end{tabular}

\section{Media exposure}

Based on the records, $94.4 \%$ of the participants experienced media exposure, and $39.7 \%$ of them updated the information on COVID-19 every day.

Table 4: Correlation of anxiety level with the frequency of media exposure per week

\begin{tabular}{|c|c|c|c|c|c|}
\hline \multirow[t]{2}{*}{ Variable } & \multirow{2}{*}{$\begin{array}{l}\text { Total } \\
(\mathrm{n}=267)\end{array}$} & \multicolumn{4}{|l|}{ Anxiety level } \\
\hline & & Severe n (\%) & Moderate n (\%) & Mild n (\%) & Normal n (\%) \\
\hline \multicolumn{6}{|c|}{ Media exposure } \\
\hline Yes & $252(94.4)$ & $28(90.3)$ & 33 (91.7) & $171(95)$ & $12(60)$ \\
\hline No & $15(5.6)$ & $3(9.7)$ & $3(8.3)$ & $9(5)$ & $8(40)$ \\
\hline Chi-square & & \multicolumn{4}{|l|}{$<0.01$} \\
\hline \multicolumn{6}{|c|}{ Frequency of media exposure about COVID-19 per week } \\
\hline Everyday & $106(39.7)$ & $13(41.9)$ & $11(30.6)$ & $73(40.6)$ & $6(30)$ \\
\hline $5-6$ days & $15(5.6)$ & $2(6.5)$ & $1(2.8)$ & $10(5.6)$ & $2(10)$ \\
\hline $3-4$ days & $60(22.5)$ & $3(9.7)$ & $12(33.3)$ & $42(23.3)$ & $1(5)$ \\
\hline $1-2$ days & $71(26.6)$ & $10(32.3)$ & $9(25)$ & $46(25.6)$ & $4(20)$ \\
\hline None & $15(5.6)$ & $3(9.7)$ & $3(8.3)$ & $9(5)$ & $7(35)$ \\
\hline Chi-square & & $<0.01$ & & & \\
\hline
\end{tabular}

As can be seen from Table 4, from 252 respondents exposed to media, $90.3 \%$ had severe anxiety, $91.7 \%$ had moderate anxiety, and 95\% experienced mild anxiety. Statistically, there was a significant correlation between media exposure and anxiety level.

Among those intended to update COVID-19 news every day, $41.9 \%$ experienced severe anxiety groups, $30.6 \%$ moderate anxiety, and $40.6 \%$ mild anxiety. Chi-square test proved that the frequency of watching, reading, or listening to the news related to COVID-19 significantly correlated with the anxiety incidence among the population.

\section{Screen time}

Based on Table 5, 94\% of the total participants spent their work time in front of electronic devices during the pandemic, $35.2 \%$ with the screen time of $\geq 8 \mathrm{~h}$ per day.

Table 5: Correlation of anxiety level with device screen-based work

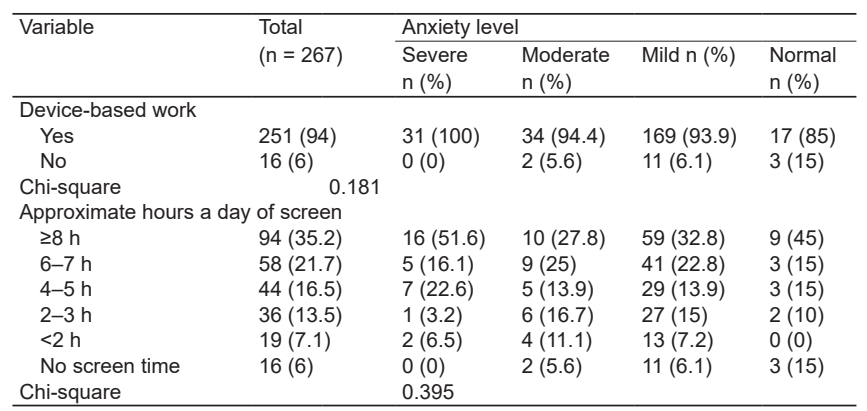

Most of the participants with severe, moderate, mild anxiety and even normal were found to work with devices a lot. However, the result of the Chi-square test showed values of 0.181 and 0.395 , suggesting a negative correlation of device-based work and approximate hours of screen time per day with anxiety level.

\section{Physical activity}

Based on physical activity, the majority of respondents $(62.2 \%)$ had a low intensity of physical activity. The correlation between anxiety and physical activity is presented in Table 6.

Table 6: Correlation of anxiety level with physical activity

\begin{tabular}{|c|c|c|c|c|c|}
\hline \multirow[t]{2}{*}{ Variable } & \multirow{2}{*}{$\begin{array}{l}\text { Total } \\
(\mathrm{n}=267)\end{array}$} & \multicolumn{4}{|l|}{ Anxiety level } \\
\hline & & Severe $\mathrm{n}(\%)$ & Moderate $\mathrm{n}(\%)$ & Mild n (\%) & Normal n (\%) \\
\hline \multicolumn{6}{|c|}{ Physical activity } \\
\hline Low & $166(62.2)$ & $21(67.7)$ & $18(50)$ & $117(65)$ & $7(35)$ \\
\hline Moderate & $75(28.1)$ & $8(25.8)$ & $10(27.8)$ & $51(28.3)$ & $5(25)$ \\
\hline High & $26(9.7)$ & $2(6.5)$ & $8(22.2)$ & $12(6.7)$ & $8(40)$ \\
\hline Chi-square & & $<0.01$ & & & \\
\hline
\end{tabular}

The results revealed that the majority of people with severe anxiety $(67.7 \%)$, moderate anxiety $(50 \%)$, and mild anxiety $(65 \%)$ had low physical activity. In contrast, $40 \%$ of normal respondents had a high intensity of physical activity.

The probability value of $<0.01$ indicated a significant correlation between anxiety level and physical activity.

\section{Anxiety diagnosis}

The history of anxiety disorder in each respondent was determined by asking for anxiety diagnosis over the last 6 months. Data collection showed that only $3 \%$ of the participants had anxiety diagnosis.

Based on the results presented in Table 7 , $12.9 \%, 2.8 \%$, and $1.7 \%$ of the participants with cliniciandiagnosed anxiety showed severe, moderate, and mild anxiety symptoms, respectively. Chi-square analysis revealed that anxiety diagnosis was significantly associated with anxiety levels. 
Table 7: Correlation of anxiety level with an anxiety diagnosis

\begin{tabular}{|c|c|c|c|c|c|}
\hline \multirow[t]{2}{*}{ Variable } & \multirow{2}{*}{$\begin{array}{l}\text { Total } \\
(n=267)\end{array}$} & \multicolumn{4}{|l|}{ Anxiety level } \\
\hline & & Severe $\mathrm{n}(\%)$ & Moderate $\mathrm{n}(\%)$ & Mild n (\%) & Normal n (\%) \\
\hline \multicolumn{6}{|c|}{ Anxiety diagnosis } \\
\hline Yes & $8(3)$ & $4(12.9)$ & $1(2.8)$ & $3(1.7)$ & $0(0)$ \\
\hline No & $259(97)$ & $27(87.1)$ & $35(97.2)$ & $177(98.3)$ & $20(100)$ \\
\hline Chi-square & & $<0.01$ & & & \\
\hline
\end{tabular}

\section{Ordinal logistics regression}

The ordinal logistics regression test, shown in Table 8, revealed that the current residence and anxiety diagnosis largely influenced anxiety among respondents. Urban people showed a higher estimated probability of being anxious compared to the rural group $(\mathrm{OR}=2.476)$. People with previous anxiety diagnoses had a higher estimated probability of being anxious.

Table 8: Likelihood of anxiety level for individuals (ordinal logistics regression)

\begin{tabular}{|c|c|}
\hline Individual characteristic & Odds ratio \\
\hline \multicolumn{2}{|l|}{ Education } \\
\hline Primary & ns \\
\hline Secondary & ns \\
\hline High & ns \\
\hline \multicolumn{2}{|l|}{ Sex } \\
\hline Male & ns \\
\hline Female & ns \\
\hline \multicolumn{2}{|l|}{ Age } \\
\hline $18-29$ & ns \\
\hline $30-49$ & ns \\
\hline $50-69$ & ns \\
\hline \multicolumn{2}{|l|}{ Occupation } \\
\hline Unemployed & ns \\
\hline Full-time employed & ns \\
\hline Part-time employed & ns \\
\hline \multicolumn{2}{|l|}{ Current residence } \\
\hline Urban & $2.476^{\circ}$ \\
\hline \multicolumn{2}{|l|}{ Rural } \\
\hline \multicolumn{2}{|l|}{ Personal income category } \\
\hline Decrease & ns \\
\hline Stable & ns \\
\hline Increase & ns \\
\hline \multicolumn{2}{|l|}{ Media exposure } \\
\hline Yes & ns \\
\hline No & ns \\
\hline \multicolumn{2}{|c|}{ Frequency of media exposure in a week } \\
\hline Everyday & ns \\
\hline $5-6$ times & ns \\
\hline $3-4$ times & ns \\
\hline $1-2$ times & $\mathrm{ns}$ \\
\hline None & ns \\
\hline \multicolumn{2}{|l|}{ Device screen-based work } \\
\hline Yes & ns \\
\hline No & ns \\
\hline \multicolumn{2}{|c|}{ Screen time during a pandemic } \\
\hline$\geq 8 \mathrm{~h}$ & ns \\
\hline $6-7 \mathrm{~h}$ & ns \\
\hline $4-5 \mathrm{~h}$ & ns \\
\hline $2-3 \mathrm{~h}$ & ns \\
\hline$<2 \mathrm{~h}$ & ns \\
\hline None & ns \\
\hline \multicolumn{2}{|l|}{ Physical activity } \\
\hline Low & ns \\
\hline Moderate & ns \\
\hline High & ns \\
\hline \multicolumn{2}{|l|}{ Anxiety diagnosis } \\
\hline Yes & $5.116^{*}$ \\
\hline No & \\
\hline
\end{tabular}

\section{Discussion}

\section{Sample characterization}

The study was conducted during the early week of the transition phase after Large-scale Social Restriction in Indonesia, in which numerous individuals were encountering emotional distress and nervousness. Although the new normal phase has started, people are still at risk of anxiety since COVID-19 has not been eliminated yet. Based on the study, $67.4 \%, 13.5 \%$, and $11.6 \%$ of the general population who participated in this research had mild, moderate, and severe anxiety, respectively. These findings are consistent with the investigations that showed approximately $25 \%$ of the overall public in China experienced moderate to extreme degrees of tension in response to COVID-19 [20].

In this study, most of the participants have lived in an urban area where they confer greater challenges and economic pressure compared to rural areas. Even though living in a metropolis can be exciting, there is also a downside. The statistical test found that current residence had a significant relationship with anxiety levels during the pandemic. Based on the ordinal logistics regression test, urban people showed a higher estimated probability of being anxious than the rural group. This result is consistent with a previous study that stated people living in cities are more likely to become mentally ill than people in rural areas due to its challenging and competitive atmosphere to survive [21]. More urban living situations are related to higher prescription rates for psychotropic medication for tension, depression, and psychological issues. Accordingly, living in an urban area can expose adults to social problems, lead them to be stressed, and contribute to poor health [22].

A recent study showed that youths living in cities often endure a high level of stressful life events, neighborhood issues, and family stress [23], [24], [25]. A meta-analysis also found that mental health conditions such as PTSD, anger management, and generalized anxiety disorder were more frequent among those living in urban areas [26]. Social issues and environmental stressors that might cause anxiety disorder are generally more prevalent in cities than in rural areas. However, it is important to keep in mind that there is no clear trend since we have a limited sample size, and there are indeed considerable risk factors, that is, poverty, social isolation, discrimination, and so forth [27]. Further insight into the association between spatial heterogeneity factors and anxiety tendency requires interdisciplinary research.

\section{Media exposure}

Media is one of the fundamental channels updating the COVID-19 data [28]. This study showed that more than $90 \%$ of participants reported being frequently exposed to COVID19-related media. Moreover, more than $90 \%$ of participants with anxiety issues, whether heavy, moderate, or low, always updated recent news about COVID-19 through any kind of media platform. Our study also revealed the probability value $<0.01$ for the relationship between media exposure of COVID19 information and self-rated anxiety. This bivariate 
correlation also had a high OR (3.481), consistent with a previous study [15]. As to gender characteristics, women had a higher tendency to be COVID-19 news addicts, more frequent among respondents aged 18-29 years old with higher education living in cities.

Furthermore, the results indicated a significant correlation between the characteristics of individuals exposed to media with anxiety levels $(p<0.01)$. Different investigations have discovered a valid link between media access and an increased risk of depression, anxiety, loneliness, self-hurt, and even self-destructive considerations [29], [30]. As another important finding, social media as the most predominant source of information was related to COVID-19. Nowadays, social media is increasingly becoming a popular and key source of health information by connecting people with health contents, experts, support, and the latest news [31]. As a result, people can easily be exposed to an uncertain source of information [32].

At the end of April 2020, a study also reported that around seven out of 10 Americans chose to take breaks from news about coronavirus, and four of 10 felt more terribly desperate due to following the news [33]. This was because, during the outbreak, disinformation and false reports have bombarded any kind of media and stoked unfounded fears among users. Hence, watching, perusing, or listening to news about COVID-19 that makes people feel on edge need to be minimized. It is essential to seek information only from trusted sources (local authorities or WHO website) and reduce the media exposure frequency. Checking the features once a day is a reasonable objective by surfing the web or reading a daily news bulletin or government announcement. The frequency could be diminished to once per week for those with an elevated anxiety level. Urgently, it is also essential to select a trusted news website with an emphasis on realities rather than conjecture [33].

\section{Screen time}

During the pandemic, people tend to spend time at home, including work, following the government's recommendation to implement working from home. Consequently, an increasing proportion of adults' time at home is spent with screens, including smartphones, tablets, laptops, and other devices [33]. The results revealed that $94 \%$ of the respondents worked with devices; $35.2 \%$ of them spent $\geq 8 \mathrm{~h}$ per day. Although there is a general tendency for anxiety symptoms to be experienced by those who work with devices, statistically, there was no correlation between screen time and anxiety. This result agreed with that obtained by Twenge et al. [34] and Babic et al. [35], but contradicted the findings of Odgers [36], and Przybylski and Weinstein [37], who reported no correlation between screen time and anxiety. However, it is crucial to understand that screen time may have essential clinical implications for the mental and even physical health of children and adolescents [34]. As mentioned, the frequency or intensity of using screens, including gadgets for different reasons, will affect their mental and emotional development [38]. People with higher screen use were more likely to have anxiety or depression [34]. Thus, more research is needed for discussing the association of screen time with mental health.

\section{Physical activity}

This study found a significant correlation between physical activity and anxiety probability. Respondents who experienced severe, moderate, and low anxiety had a low intensity of physical activity. Like the rest of the world, Indonesians have seen drastic changes in their lives due to the large-scale social restriction as a part of the public health emergency response. It has affected the routine of their daily activities by restricting outdoor activities, except for urgent reasons. The policy of large scale restrictions may provoke new unhealthy habits while staying at home. Although the public health priority aims to protect Indonesians under such circumstances, the unintended outcomes may include decreased physical movement and expansion in inactive conduct that might lead to chronic health conditions [39].

Statistically, physical activity was not a risk factor for anxiety; however, it is true that grown-ups who are consistently physically active experience fewer symptoms of anxiety and depression [10], [12]. Furthermore, regular exercise brings physiological changes and adaptations in the human body. Studies have indicated that physical activity and exercise are successful treatments for the vast majority of interminable illnesses with direct impacts on both mental and physical well-being [20]. Exercise has proved to positively influence the surrogate measure of adult hippocampal neurogenesis such as $\beta$-endorphins, vascular endothelial growth factor, BDNF, and serotonin, all of which are thought to be the common pathophysiologic mechanism for anxiety disorder [40]. Thus, the inactive participants who were more dynamic or maintained their exercise levels demonstrated more elevated levels of social, emotional, and psychological health and lower levels of generalized anxiety [41], [42]. Accordingly, it is appropriate for citizens to do sports and other activities to preserve physical and mental health. These findings agree with the $\mathrm{WHO}$ recommendation to learn a simple daily exercise to perform at home in quarantine or isolation to keep up portability and diminish fatigue [2].

\section{Anxiety diagnosis}

Participants' report of a previously diagnosed depression or other mental health disorders by a 
health professional is frequently used to estimate the prevalence rate. In a large-scale health review, the prevalence of anxiety was surveyed by asking respondents whether they were diagnosed with anxiety by a health professional over the past year [16].

Based on the observations, $12.9 \%, 2.8 \%$, and $1.7 \%$ of participants with clinician-diagnosed anxiety had symptoms of severe, moderate, and mild anxiety, respectively. Ordinal logistics regression showed that people with anxiety diagnoses had a higher estimated probability of being anxious than those without any anxiety history. These findings suggested that anxiety diagnosis may influence the result of such research. Besides, anxiety diagnosis was more common among women aged 18-29 years old. These results were consistent with the findings of McLean et al. [43], who showed the lifetime and 12 months male:female prevalence ratios of any anxiety disorders are 1:1.7 and $1: 1.79$, respectively. In general, women tended to have higher frequencies of affective disorders (such as depression and anxiety) than men. Furthermore, anxiety disorders are more disabling in women than in men [43].

\section{Conclusion}

This study proved that age, education, income, media exposure, physical activity, and anxiety diagnosis associated with anxiety levels. However, ordinal logistics regression revealed that only respondents living in the city and individuals diagnosed with anxiety disorders were more likely to experience anxiety symptoms during the COVID-19 pandemic in Indonesia (OR >1).

\section{Limitation of the study}

This study had limited access to rural respondents due to restricted internet access. As a result, the number of samples from villages was not representative enough. Moreover, the present study was cross-sectional research that could not help to determine cause and effect.

\section{References}

1. Wuhan Municipal Health Commission. Report of Clustering Pneumonia of Unknown Etiology in Wuhan City. Wuhan, China: Wuhan Municipal Health Commission; 2020. Available: http:/l www.wjw.wuhan.gov.cn/front/web/showDetail/2019123108989. [Last accessed 2019 Dec 31]. https://doi.org/10.30919/ esfaf0002

2. World Health Organization. Mental Health and Psychosocial Considerations during the COVID-19 Outbreak. Geneva: World
Health Organization; 2020. Available from: https://www.who. int/publications/i/item/WHO-2019-nCoV-MentalHealth-2020.1. [Last accessed 2020 Mar 18]. https://doi.org/10.1037/ e400972004-001

3. Kementerian Kesehatan Republik Indonesia. COVID-19 Dalam Angka. Jakarta, Indonesia: Kementerian Kesehatan Republik Indonesia; 2020. Available from: http://www.kemkes.go.id. [Last accessed on 2020 Jun 03]. https://doi.org/10.24198/padjir. v1i4.26242

4. Djalante R, Lassa J, Setiamarga D, Sudjatma A, Indrawan M, Haryanto B, Mahfud C, et al. Review and analysis of current responses to COVID-19 in Indonesia: Period of January to March 2020. Prog Disaster Sci. 2020;6:100091. https://doi. org/10.1016/j.pdisas.2020.100091

5. Wulandari P, Hidayat R. General anxiety disorder-related coronavirus disease-19 outbreak in Indonesia: A case report. Open Access Maced J Med Sci. 2020;8(T1):36-8. https://doi. org/10.3889/oamjms.2020.4762

6. Gatineau M, Dent M. Obesity and Mental Health. Oxford: National Obesity Observatory; 2011.

7. American Psychiatric Association. Diagnostic and Statistica Manual of Mental Disorders. $5^{\text {th }}$ ed. Arlington, VA: American Psychiatric Publishing; 2013.

8. Blakey SM, Abramowitz JS. Psychological predictors of health anxiety in response to the Zika virus. J Clin Psychol Med Settings. 2017;24(3-4):270-8. https://doi.org/10.1007/s10880-017-9514-y PMid:29063232

9. Zhang Y, Ma ZF. Impact of the COVID-19 pandemic on menta health and quality of life among local residents in Liaoning Province, China: A cross-sectional study. Int J Environ Res Public Health. 2020;17(7):2381. https://doi.org/10.3390/ ijerph17072381

PMid:32244498

10. Boswell JF, Thompson-Hollands J, Farchione TJ, Barlow DH Intolerance of uncertainty: A common factor in the treatment of emotional disorders. J Clin Psychol. 2013;69(6):630-45. https:// doi.org/10.1002/jclp.21965 PMid:23381685

11. Khosravi M. Stress reduction model of COVID-19 pandemic. Iran J Psychiatry Behav Sci. 2020;14(2):e103865. https://doi. org/10.5812/ijpbs.103865

12. Van Minnen A, Hendriks L, Olff M. When do trauma experts choose exposure therapy for PTSD patients? A controlled study of therapist and patient factors. Behav Res Ther. 2010;48(4):31220. https://doi.org/10.1016/j.brat.2009.12.003 PMid:20056195

13. Pengpid S, Peltzer K. High sedentary behaviour and low physica activity are associated with anxiety and depression in Myanmar and Vietnam. Int J Environ Res Public Health. 2019;16(7):1251. https://doi.org/10.3390/ijerph16071251

PMid:30965618

14. Neria Y, Sullivan GM. Understanding the mental health effects of indirect exposure to mass trauma through the media. JAMA 2011;306(12):1374-5. https://doi.org/10.1001/jama.2011.1358 PMid:21903818

15. Mertens G, Gerritsen L, Duijndam S, Salemink E, Engelhard IM. Fear of the coronavirus (COVID-19): Predictors in an online study conducted in March 2020. J Anxiety Disord. 2020;74:102258. https://doi.org/10.1016/j.janxdis.2020.102258

16. Holman EA, Garfin DR, Silver RC. Media's role in broadcasting acute stress following the Boston Marathon bombings. Proc Natl Acad Sci U S A. 2014;111(1):93-8. https://doi.org/10.1073/ pnas. 1316265110

PMid:24324161

17. Chatterjee SS, Barikar CM, Mukherjee A. Impact of 
COVID-19 pandemic on pre-existing mental health problems. Asian J Psychiatr. 2020;51:102071. https://doi.org/10.1016/j. ajp.2020.102071

PMid:32334407

18. Ramdan IM. Reliability and validity test of the indonesian version of the hamilton anxiety rating scale (HAM-A) to measure workrelated stress in nursing. J NERS. 2019;14(1):33-40. https://doi. org/10.20473/jn.v14i1.10673

19. Craig CL, Marshall AL, Sjöström M, Bauman AE, Booth ML, Ainsworth $\mathrm{BE}$, et al. International physical activity questionnaire: 12-country reliability and validity. Med Sci Sports Exerc. 2003;35(8):1381-95. https://doi.org/10.1249/01. MSS.0000078924.61453.Fb PMid:12900694

20. Qiu J, Shen B, Zhao M, Wang Z, Xie B, Xu Y. A nationwide survey of psychological distress among Chinese people in the COVID-19 epidemic: Implications and policy recommendations. Gen Psychiatry. 2020;33(2):e100213. https://doi.org/10.1136/ gpsych-2020-100213.

21. Willie TC, Powell A, Kershaw T. Stress in the city: Influence of urban social stress and violence on pregnancy and postpartum quality of life among adolescent and young mothers. J Urban Health. 2016;93(1):19-35. https://doi.org/10.1007/ s11524-015-0021-x

PMid:26791234

22. Bennett MD Jr., Miller DB. An exploratory study of the Urban Hassles Index: A contextually relevant measure of chronic multidimensional urban stressors. Res Soc Work Pract. 2006;16(3):305-14. https://doi.org/10.1177/1049731505283886

23. Tobler AL, Maldonado-Molina MM, Staras SA, O'Mara RJ, Livingston MD, Komro KA. Perceived racial/ethnic discrimination, problem behaviors, and mental health among minority urban youth. Ethn Health. 2013;18(4):337-49. https://doi.org/10.1080 /13557858.2012.730609

PMid:23043428

24. Landis D, Gaylord-Harden NK, Malinowski SL, Grant KE, Carleton RA, Ford RE. Urban adolescent stress and hopelessness. J Adolesc. 2007;30(6):1051-70. https://doi. org/10.1016/j.adolescence.2007.02.001

PMid:17467052

25. Stueve A, O'Donnell L. Urban young women's experiences of discrimination and community violence and intimate partner violence. J Urban Health. 2008;85(3):386-401. https://doi. org/10.1007/s11524-008-9265-z

PMid: 18347993

26. Gruebner O, Rapp MA, Adli M, Kluge U, Galea S, Heinz A. Cities and mental health. Dtsch Arztebl Int. 2017;114(8):121-7. https://doi.org/10.3238/arztebl.2017.0121 PMid:28302261

27. Subbaraman R, Nolan L, Shitole T, Sawant K, Shitole S, Sood K, et al. The psychological toll of slum living in Mumbai, India: A mixed methods study. Soc Sci Med. 2014;119:155-69. https:// doi.org/10.1016/j.socscimed.2014.08.021 PMid:25189736

28. Bao Y, Sun Y, Meng S, Shi J, Lu L. 2019-nCoV epidemic: Address mental health care to empower society. Lancet. 2020;395(10224):e37-8. https://doi.org/10.1016/ S0140-6736(20)30309-3

PMid:32043982

29. Gao J, Zheng P, Jia Y, Chen H, Mao Y, Chen S, et al. Mental health problems and social media exposure during COVID19 outbreak. PLoS One. 2020;15(4):e0231924. https://doi. org/10.1371/journal.pone.0231924

PMid:32298385
30. Niederkrotenthaler T, Stack S, Till B, Sinyor M, Pirkis J, Garcia D, et al. Association of increased youth suicides in the United States with the release of 13 reasons why. JAMA Psychiatry. 2019;76(9):933-40. https://doi.org/10.1001/ jamapsychiatry.2019.0922

PMid:31141094

31. Common Sense Media. The Common Sense Census: Media Use by Tweens and Teens; 2015. Available from: https://www. commonsensemedia.org/about-us/news/press-releases/ landmark-report-us-teens-use-an-average-of-nine-hours-ofmedia-per-day. [Last accessed on 2015 Nov 03].

32. Khosravi M. Perceived risk of COVID-19 pandemic: The role of public worry and trust. Electron J Gen Med. 2020;17(4):em203. https://doi.org/10.29333/ejgm/7856

33. Mitchell A, Oliphant JB, Shearer E. About Seven-in-Ten U.S Adults say they Need to Take Breaks from COVID-19 News; 2020. Available from: https://www.journalism.org/2020/04/29/ about-seven-in-ten-u-s-adults-say-they-need-to-take-breaksfrom-covid-19-news. [Last accessed on 2020 Apr 29].

34. Twenge JM, Campbell WK. Associations between screen time and lower psychological well-being among children and adolescents: Evidence from a population-based study. Prev Med Rep. 2018;12:271-83. https://doi.org/10.1016/j. pmedr.2018.10.003

35. Babic MJ, Smith JJ, Morgan PJ, Eather N, Plotnikoff RC, Lubans DR. Longitudinal associations between changes in screen-time and mental health outcomes in adolescents. Ment Health Phys Act. 2017;12:124-31. https://doi.org/10.1016/j. mhpa.2017.04.001

36. Odgers C. Smartphones are bad for some adolescents, not all. Nature. 2018;554(7693):432-4. https://doi.org/10.1038/ d41586-018-02109-8

PMid:29469108

37. Przybylski AK, Weinstein N. A large-scale test of the goldilocks hypothesis: Quantifying the relations between digital-screen use and the mental well-being of adolescents. Psychol Sci. 2017;28(2):204-15. https://doi.org/10.1177/0956797616678438

38. Wahyuni AS, Siahaan FB, ArfaM, Alona I, Nerdy N. The relationship between the duration of playing gadget and mental emotional state of elementary school students. Open Access Maced J Med Sci. 2019;7(1):148-51. https://doi.org/10.3889/ oamjms.2019.037

39. Chen P, Mao L, Nassis GP, Harmer P, Ainsworth BE, Li F. Coronavirus disease (COVID-19): The need to maintain regular physical activity while taking precautions. J Sport Health Sci. 2020;9(2):103-4. https://doi.org/10.1016/j.jshs.2020.02.001 PMid:30740180

40. Anderson EH, Shivakumar G. Effects of exercise and physical activity on anxiety. Front Psychiatry. 2013;4:27. https://doi. org/10.3389/fpsyt.2013.00027

PMid:23630504

41. Lesser IA, Nienhuis CP. The Impact of COVID-19 on physical activity behavior and well-being of Canadians. Int $\mathrm{J}$ Environ Res Public Health. 2020;17(11):3899. https://doi.org/10.3390/ ijerph17113899

PMid:32486380

42. Stults-Kolehmainen MA, Sinha R. The effects of stress on physical activity and exercise. Sports Med. 2014;44(1):81-121. https://doi.org/10.1007/s40279-013-0090-5 PMid:24030837

43. McLean CP, Asnaani A, Litz BT, Hofmann SG. Gender differences in anxiety disorders: Prevalence, course of illness, comorbidity and burden of illness. J Psychiatr Res. 2011;45(8):1027-35. https://doi.org/10.1016/j.jpsychires.2011.03.006

PMid:21439576 